\title{
Impact of Normal and Shear Stresses Due to Wheel Slip on Hydrological Properties of an Agricultural Clay Loam: Experimental and New Computerized Approach
}

\author{
Andrea Battiato $^{1,3}$, Abdallah Alaoui ${ }^{2}$ \& Etienne Diserens ${ }^{1}$ \\ ${ }^{1}$ Agroscope, Institute for Sustainability Sciences (ISS), Ettenhausen, Switzerland \\ ${ }^{2}$ Centre for Development and Environment (CDE), University of Bern, Bern, Switzerland \\ ${ }^{3}$ Department of Land, Environment, Agriculture and Forestry, University of Padua, Legnaro, Italy \\ Correspondence: Etienne Diserens, Agroscope, Institute for Sustainability Sciences ISS, Tänikon 1, 8356 \\ Ettenhausen, Switzerland. Tel: 41-58-480-3353. E-mail: etienne.diserens@agroscope.admin.ch
}

Received: November 2, 2014 Accepted: December 5, 2014 Online Published: March 15, 2015

doi:10.5539/jas.v7n4p1 URL: http://dx.doi.org/10.5539/jas.v7n4p1

\begin{abstract}
The main purpose of this study was to evaluate the effect that mechanical stresses acting under the slipping driving wheels of agricultural equipment have on the soil's pore system and water flow process (surface runoff generation during extreme event). The field experiment simulated low slip (1\%) and high slip (27\%) on a clay loam. The stress on the soil surface and changes in the amounts of water flowing from macropores were simulated using the Tires/tracks And Soil Compaction (TASC) tool and the MACRO model, respectively. Taking a $65 \mathrm{~kW}$ tractor on a clay loam as a reference, results showed that an increase in slip of the rear wheels from $1 \%$ to $27 \%$ caused normal stress to increase from $90.6 \mathrm{kPa}$ to $104.4 \mathrm{kPa}$ at the topsoil level, and the maximum shear contact stress to rise drastically from $6.0 \mathrm{kPa}$ to $61.6 \mathrm{kPa}$. At $27 \% \mathrm{slip}$, topsoil was sheared and displaced over a distance of $0.35 \mathrm{~m}$. Excessive normal and shear stress values with high slip caused severe reductions of the soil's macroporosity, saturated hydraulic conductivity, and water quantities flowing from topsoil macropores. Assuming that, under conditions of intense rainfall on sloping land, a loss in vertical water flow would mean an increase in surface runoff, we calculated that a rainfall intensity of $100 \mathrm{~mm} \mathrm{~h}^{-1}$ and a rainfall duration of $1 \mathrm{~h}$ would increase the runoff coefficient to 0.79 at low slip and to 1.00 at high slip, indicating that $100 \%$ of rainwater would be transformed into surface runoff at high slip. We expect that these effects have a significant impact on soil erosion and floods in steeper terrain (slope $>15^{\circ}$ ) and across larger surface areas $\left(>16 \mathrm{~m}^{2}\right)$ than those included in our study.
\end{abstract}

Keywords: MACRO model, macroporosity, surface runoff, saturated hydraulic conductivity, normal stress, shear stress, TASC tool, wheel slip

\section{Introduction}

The structure of the soil profile down to a depth of $0.6 \mathrm{~m}$ can be affected by farming in many ways depending on the characteristics of the machines, the soil type, and the initial soil conditions (e.g. Ansorge \& Godwin, 2006; Arvidsson, Trautner, \& Keller, 2002; Horn, 2003). Considering topsoil alteration, wheeled agricultural equipment, especially tractors with mounted or trailed implements, exert traction force through a stress-strain interaction between the tires and the topsoil. In this contact surface interaction between soil and tire, soil deforms under normal and shear stresses (eg. Horn, 2002; Horn \& Rostek, 2000). The shear stress rises sharply with an increase in traction force and wheel slip, which may lead to the detachment of a weak topsoil layer vulnerable to erosion due to soil failure (Battiato, Diserens, Laloui, \& Sartori, 2013).

The effect of soil deformation on soil structure can be assessed with several types of parameters: bulk density and total porosity (Boone, 1988; da Silva, Kay, \& Perfect, 1994), macroporosity (Alakukku, 1996), penetration resistance (Pagliai, 1998), air permeability (Ball, 1981; Reszkowska, Krümmelbein, Gan, Peth, \& Horn, 2011), saturated hydraulic conductivity (Alakukku, 1996), pre-consolidation pressure (Horn, 1981; Kirby, 1991), dye surface density (Kulli, Gysi, \& Flühler, 2003; Alaoui \& Helbling, 2006; Alaoui \& Goetz, 2008), and infiltration capacity (Alaoui \& Helbling, 2006; Blanco-Canqui, Claassen, \& Stone, 2010). 
The most-used ones are soil cohesion, soil structural strength, bulk density, water potential, and pre-compressive stress. However, these parameters are general indicators that integrate information about the total change in the volume of voids of soil under consideration, but they cannot account for changes in the volume distribution of these voids, their connectivity, or the changes in this connectivity (e.g., Vogeler, Horn, Wetzel, \& Kruemmelbein, 2006).

Previous investigations showed that shear stress induces a tortuous pore system with vertical and horizontal soil displacement (Wiermann, 1998), a decrease in air permeability (O'Sullivan, Robertson, \& Henshall, 1999), and an excess in surface runoff during strong rainfall (Horn \& Rostek, 2000). Models of the driving forces acting at the soil-tire interface related to slip (Steiner, 1979; Osetinsky \& Shmulevich, 2004), to the deformation of the tires and the topsoil during tractive performance (Schwieger, 1996), or to the management of the energy requirement of the tractor (Pichlmaier, 2012) described the stresses and deformation distribution of soil and tire but did not provide direct information useful to the practitioner.

Based on field and laboratory studies, computerized simulations emerged as appropriate tools to evaluate the effects of heavy-load machines on soil compaction. They included mapping on a national scale with the Soil Compaction Model (SOCOMO) (van den Akker, 1997, 2004) or on a plot scale (Diserens, Chanet, \& Marionneau, 2010) and can be designed as practical applications such as Terranimo ${ }^{\circledR}$ (Stettler et al., 2010) and Tyres/tracks And Soil Compaction (TASC) (Diserens \& Spiess, 2004). A practical forecasting module integrated into TASC V3.0 (Battiato, 2014; Diserens \& Battiato, 2013) calculates the slip-rate limit beyond which the topsoil failure occurs with the corresponding traction force.

Although the above approaches provide useful information on the mechanical disturbance of soil structure in order to better manage agricultural land, they do not elucidate the risk of erosion or flooding during heavy rainfall in hillslope soils.

Today, several hydrological methods are used to estimate surface runoff on different landscape scales. These methods are based on soil topography, geology, vegetation cover, and soil type (Peschke, Etzenberg, Müller, Töpfer, \& Zimmermann, 1999; Scherrer \& Naef, 2003; Markart et al., 2004). Additional tools that assess the flow processes in topsoil by using input soil parameters in response to a given rainfall or irrigation intensity (e.g., Jarvis, 1994; Simunek, Sejna, \& van Genuchten, 2007) do not consider external perturbations caused by land use. Surprisingly, no or insufficient attempts have been made in field experiments or computer simulations to identify cause-and-effect relationships between the magnitude of shear stress and normal stress applied by agricultural machines and the changes in the soil water dynamics. Knowledge of these relationships would be of great relevance to the practitioner for a better soil and water management on steep grounds used for agriculture, especially in conservation systems without plowing.

In addition to mechanical components, climate change will modify the hydrological regime in many regions and consequently the water dynamics in unsaturated soil. Based on regional climate models (Christensen \& Christensen, 2003; Graham, Hagemann, Jaun, \& Beniston, 2007), future summers are likely to show more frequent extreme events that result in catastrophic flooding, despite a general trend toward drier summer conditions. Thus, increasing rainfall intensity and soil compaction magnitude should drastically increase surface runoff that would promote flood events and erosion during extreme rainfall events.

The aim of this study was to evaluate the impact of mechanical stresses acting at the soil-tire interface during wheel slip on soil structure - parameterized as total porosity, pore-size distribution, saturated hydraulic conductivity, and Brilliant Blue dye-tracer distribution - and, consequently, on water flow process (water flowing from macropores and surface runoff). To achieve this goal, we measured and modelled both, mechanical and hydraulic properties.

\section{Material and Methods}

\subsection{Location and Soil Description}

The two study sites were located in Tänikon $\left(47^{\circ} 29^{\prime} 0^{\prime \prime} \mathrm{N}, 8^{\circ} 54^{\prime} 44^{\prime \prime} \mathrm{E}\right)$ in the canton of Thurgovie, in Eastern Switzerland, on the border of the Prealps at 536 m.a.s.l. The annual mean rainfall values over the last decade amounted to $1140 \mathrm{~mm}$ with peaks in May and July/August. The study area was situated on a plain where land cover consisted of wheat stubble. The soil was described as albic luvisol (USA classification) (Scheffer \& Schachtschabel, 1998). At both sites, soil texture consisted of clay loam to a depth of $0.45 \mathrm{~m}$. Soil organic carbon content (determined by weight loss on ignition) varied from $2 \%$ (topsoil) to $0.2 \%$ (subsoil). A pH of 7.0-7.2 was measured at the soil surface, increasing slightly to 7.4 in the subsoil (Table 1). The treatments were carried out on August $26^{\text {th }}, 2008$, under dry topsoil conditions above $0.15 \mathrm{~m}$ and relatively wet conditions below this depth. 
Table 1. Physical and hydraulic parameters of soil under consideration

\begin{tabular}{|c|c|c|c|c|c|c|c|c|}
\hline \multirow{2}{*}{$\begin{array}{l}\text { Depth interval } \\
\text { (m) }\end{array}$} & \multicolumn{3}{|c|}{ Particle-size distribution (\%) } & \multirow[b]{2}{*}{ Texture } & \multirow{2}{*}{$\begin{array}{l}\text { Organic carbon } \\
\text { OC }(\%)\end{array}$} & \multirow[b]{2}{*}{$\mathrm{pH}$} & \multirow{2}{*}{$\begin{array}{l}\text { Water content* } \\
(\%)\end{array}$} & \multirow{2}{*}{$\begin{array}{l}\text { Water potential* } \\
(\mathrm{hPa})\end{array}$} \\
\hline & $\begin{array}{l}\text { Clay } \\
(<2 \mu \mathrm{m})\end{array}$ & $\begin{array}{l}\text { Silt } \\
(2-50 \mu \mathrm{m})\end{array}$ & $\begin{array}{l}\text { Sand } \\
(>50 \mu \mathrm{m})\end{array}$ & & & & & \\
\hline \multicolumn{9}{|l|}{ Site 1} \\
\hline $0.00-0.15$ & 37.0 & 39.2 & 23.8 & clay loam & 2.0 & 7.0 & 29.05 & 28.75 \\
\hline $0.31-0.45$ & 36.7 & 37.2 & 26.1 & clay loam & 1.0 & 7.4 & 36.30 & 5.31 \\
\hline $0.46-0.50$ & 44.6 & 23.3 & 32.1 & clay & 0.2 & 7.4 & 27.05 & 0.88 \\
\hline \multicolumn{9}{|l|}{ Site 2} \\
\hline $0.00-0.15$ & 36.3 & 41.0 & 22.7 & clay loam & 2.0 & 7.2 & - & - \\
\hline $0.31-0.45$ & 37.3 & 40.2 & 22.5 & clay loam & 1.0 & 7.4 & - & - \\
\hline $0.46-0.50$ & 35.2 & 30.1 & 34.7 & clay loam & 0.2 & 7.4 & - & - \\
\hline
\end{tabular}

Note. ${ }^{*}$ Recorded data only at site 1 - treatment with $1 \%$ slip; Site 2: treatment with $27 \%$ slip; Textural classification according to the soil taxonomy of the U.S. Department of Agriculture (USDA).

\subsection{Measurements}

\subsubsection{Mechanical Properties}

\section{1) Traction Tests}

The aim of the field traction tests was to investigate the effects of tractor-tire slip on the soil. Two corridors, each $4 \mathrm{~m}$ wide and $70 \mathrm{~m}$ long, were marked in the field (Figure 1). In the first corridor (site 1), the tractor moved with minimal slip in a self-propelled, steady-state condition, whereas in the second corridor (site 2), the tractor moved with slip in a steady-state condition with high drawbar pull. A drawbar pull of $21.8 \mathrm{kN}$ was controlled by a braking tractor. Whereas almost no wheel slip (1\%) was measured at site 1, a wheel slip of $27 \%$ was measured at site 2. The pulling tractor and the braking tractor did not move in alignment. This allowed the two tractors to have independent tracks, so that the soil at site 2 was trafficked by the pulling tractor only (Figure 1). An area adjacent to the two sites served as an untreated control site (without traffic).
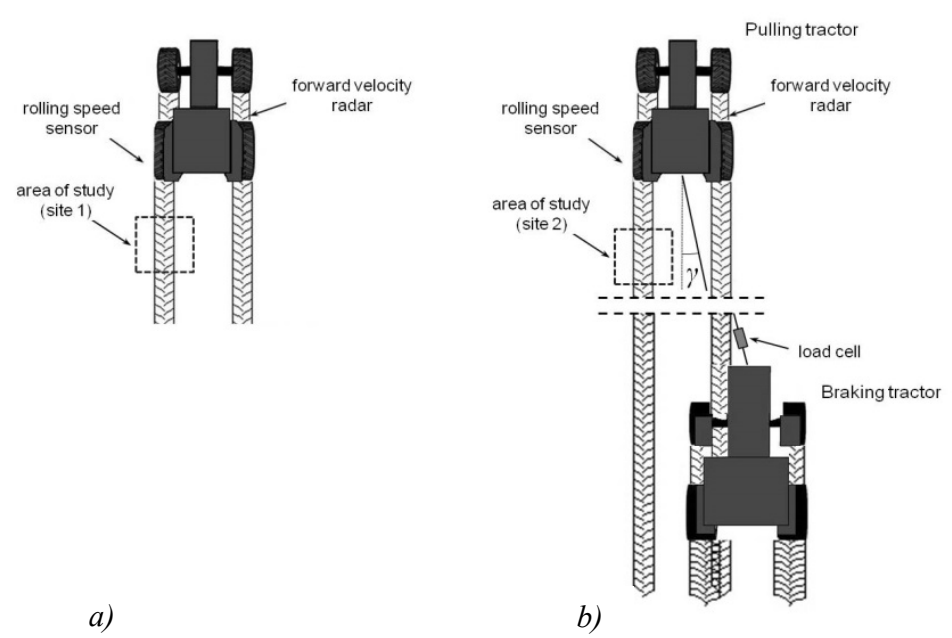

Figure 1. Experimental design of the treatments, a) traffic with low slip 1\% (site 1), b) traffic with high slip $27 \%$ (site 2)

A mechanical front-wheel drive Hürlimann H488 DT tractor with $65 \mathrm{~kW}$ engine power and $40.0 \mathrm{kN}$ weight was employed as a pulling tractor. The braking tractor was a Massey Ferguson 8470 with $250 \mathrm{~kW}$ engine power and $90.6 \mathrm{kN}$ weight (Table 2). 
Table 2. Technical data of the tractors used in the traction tests

\begin{tabular}{ll}
\hline Braking tractor & Massey Ferguson 8470 \\
\hline Power $(\mathrm{kW})$ & 250 \\
Weight $(\mathrm{kN})$ & 90.6 \\
\hline Pulling tractor & Hürlimann H488 DT \\
\hline Power $(\mathrm{kW})$ & 65 \\
Weight $(\mathrm{kN})$ & 40 \\
Wheelbase (m) & 2.34 \\
Tire (front; rear) & $380 / 85 \mathrm{R} 24 ; 420 / 85 \mathrm{R} 34$ \\
Tire width (front; rear) (m) & $0.38 ; 0.44$ \\
Tire unloaded radius (front; rear) (m) & $0.63 ; 0.79$ \\
Tire rolling radius (front; rear) $(\mathrm{m})$ & $0.59 ; 0.78$ \\
Tire inflation pressure (front; rear) $(\mathrm{kPa})$ & $160 ; 160$ \\
Tire stiffness (front; rear) $(\mathrm{kN} / \mathrm{m})$ & $325 ; 432$ \\
Stationary wheel load (front; rear) $(\mathrm{kN})$ & $9.1 ; 10.9$ \\
Drawbar height (m) & 0.83 \\
Theoretical speed ratio & 0.99 \\
\hline
\end{tabular}

The traction force was measured by a $200 \mathrm{kN}$ load cell (HBM U2B, Darmstadt, Germany) in section with the steel cable that connected the two tractors. The actual forward speed was measured by a radar velocity sensor (Dickey-john RVS2, Auburn, Illinois, U.S.A.), and the wheel rolling speed was recorded with a wireless wheel-speed sensor at two pulses per wheel revolution, set on a rear wheel of the pulling tractor. All of the above parameters were recorded by a data logger. The load acting on the wheels of the pulling tractor in the stationary condition was measured with a flat-bed wheel-load scale (Haenni WL 103, Jegenstorf, Switzerland). The pulling tractor was equipped with 380/85R24 front tires and 420/85R 34 rear tires. Tire inflation pressure was measured with a Motometer tire-pressure gauge (Mühlacker-Lomersheim, Germany) and adjusted to $160 \mathrm{kPa}$ on front and rear wheels. The rolling radius and the theoretical speed ratio of the tractor wheels, defined as the distance traveled per revolution of the wheel divided by 2 , and as the ratio of the theoretical speed of the front wheel to that of the rear wheel, respectively, were determined during preliminary tests at zero drawbar pull on a smooth road. Tire stiffness was calculated according to Lines and Murphy (1991). The technical specifications of the pulling and braking tractors are reported in Table 2. The pulling tractor moved in a rectilinear direction with locked differential. The traction force in the longitudinal direction was obtained from the measured force by taking into account the angle $\gamma$ (approx. $3^{\circ}$ ) of the steel cable that connected the two tractors (Figure 1). The actual forward speed of the tractor was $1.6 \mathrm{~m} \mathrm{~s}^{-1}$ at site 1 and $0.9 \mathrm{~m} \mathrm{~s}^{-1}$ at site 2 .

The shear magnitude related to the slip was evaluated by marking the soil surface with two differently colored dyes, blue and red, before the passage of the tractor. The food color Brilliant Blue FCF (E-133) was applied at $120 \mathrm{~L} \mathrm{~m}^{-2}$ and $3.7 \mathrm{~g} / 10^{-3} \mathrm{~m}^{3}$; the food color Allura Red (E-129) was applied at $120 \mathrm{~L} \mathrm{~m}^{-2}$ and $7.4 \mathrm{~g} / 10^{-3} \mathrm{~m}^{3}$. After the treatment, soil-layer displacement was measured.

2) Topsoil Mechanical Parameters

Topsoil mechanical parameters for simulating soil-tire interaction were obtained by vertical plate penetration tests and horizontal plate shear deformation tests according to Bekker (1960), with a tractor-mounted hydraulic press (bevameter) described by Diserens and Steinmann (2003) (Table 3).

The vertical plate penetration tests were carried out with two circular plates of diameter $0.2 \mathrm{~m}$ and $0.3 \mathrm{~m}$ at a penetration rate of approx. $0.02 \mathrm{~m} \mathrm{~s}^{-1}$. The cohesive and frictional moduli of deformation, $K c$ and $K \varphi$, respectively, and the exponent of deformation $n$ were determined according to Wong (1980).

The horizontal plate shear deformation tests were performed by using an annular plate with an outer diameter of $0.3 \mathrm{~m}$ and an inner diameter of $0.2 \mathrm{~m}$, at different vertical pressures. Values of cohesion $c$, angle of shear resistance $\varphi$, and shear deformation modulus $k$ were determined according to the procedure described by Wong 
(1980).

Penetration resistance was determined by using a penetrometer with a screwdriver head (tip width: $6 \times 10^{-3} \mathrm{~m}$ ) developed by Agroscope Tänikon (Bastgen \& Diserens, 2009). All the measured mechanical soil properties are reported in Table 3. Based on measured tractor and soil parameters, the shear stress $\tau$ and normal stress $\sigma$ occurring at the soil-tire interface were calculated according to Osetinsky and Shmulevich (2004).

Table 3. Mechanical parameters of soil under consideration

\begin{tabular}{ll}
\hline Depth interval $(\mathrm{m})$ & $0-0.20$ \\
Cohesive modulus of deformation $K_{c}\left(\mathrm{kN} \mathrm{m}^{-(n+1)}\right)$ & 4555 \\
Frictional modulus of deformation $K_{\varphi}\left(\mathrm{kN} \mathrm{m}^{-(n+2)}\right)$ & -3037 \\
Modulus of deformation $K\left(\mathrm{kN} \mathrm{m}^{-(\mathrm{n}+2)}\right)$ & 8073 \\
Exponent of deformation $n$ & 0.90 \\
Cohesion $c(\mathrm{kPa})$ & 5.0 \\
Angle of shear resistance $\varphi\left(^{\circ}\right)$ & 30.0 \\
Shear deformation modulus $k(\mathrm{~m})$ & 0.01 \\
Mean penetration resistance $\mathrm{PR}_{10 \mathrm{~cm}}(\mathrm{daN})(\mathrm{n}=24)$ & 7.51 \\
\hline
\end{tabular}

\subsubsection{Hydrological Properties}

1) Total Porosity and Pore-Size Distribution

Total porosity (TP) and pore-size distribution (PSD) were determined for samples of undisturbed soil (five per depth) with a diameter of $55 \mathrm{~mm}$ and a height of $42 \mathrm{~mm}$. The TP was measured at depths of $0-0.15,0.16-0.30$, $0.31-0.45$, and $0.46-0.60 \mathrm{~m}$, whereas PSD was measured at depths of $0.05,0.15$, and $0.35 \mathrm{~m}$. The samples were taken at intervals of about $0.15 \mathrm{~m}$ in a horizontal direction. Three pore classes were defined: macropores, i.e., pores larger than $50 \mu \mathrm{m}$; mesopores, measuring between 0.2 and $50 \mu \mathrm{m}$; and micropores, i.e., those smaller than $0.2 \mu \mathrm{m}$.

The PSD was determined by a vacuum pressure membrane apparatus described by Dirksen (1999) with a hanging water column for a water suction $h<31.6 \mathrm{kPa}$ and with a gas adsorption porosimeter using $\mathrm{N}_{2}$ for 31.6 $\mathrm{kPa}<h<1585 \mathrm{kPa}$.

\section{2) Saturated Hydraulic Conductivity}

Saturated hydraulic conductivity $\left(K_{\text {sat }}\right)$ was measured in undisturbed soil samples (five per depth) taken along the track trafficked with $1 \%$ slip (site 1), along the track trafficked with $27 \%$ slip (site 2) (Figure 1), and from an untrafficked area of the field (control site). Water conductivity measurements were carried out according to the constant head method (Klute \& Dirksen, 1986).

Samples from the topsoil surface below the loose layer $(0.03-0.07 \mathrm{~m})$ were taken after removal of the soil cut by the tire lugs. Additional samples were collected deeper in the topsoil $(0.13-0.17 \mathrm{~m})$ and in the subsoil $(0.33-0.37$ $\mathrm{m})$.

\section{3) Irrigation Experiments}

From a pit, $1 \mathrm{~m}$ deep, three water content probes were installed horizontally under both sites (site 1 and site 2). The two sites were irrigated with a rainfall simulator covering a $1 \mathrm{~m}^{2}$ area with an intensity of $30 \mathrm{~mm} \mathrm{~h}^{-1}$ for $1 \mathrm{~h}$. Water content was measured at the three depths of $0.15,0.35$, and $0.50 \mathrm{~m}$ with a time domain reflectometer (TDR) (CR10X \& TDR100, Campbell Scientific Inc. Logan, Utah, USA) with $0.20 \mathrm{~m}$ wave guides (two parallel rods of $6 \mathrm{~mm}$ diameter). Calibration was performed according to Roth, Schulin, Flühler, and Attinger (1990). The TDR measurements were recorded every $60 \mathrm{~s}$.

The results obtained were analyzed according to the decrease in water content $(\theta)$ after cessation of infiltration during the drainage phase $\left(\Delta \theta_{d}\right.$, defined as the difference between maximum water content reached at the infiltration phase and minimum water content measured within $2 \mathrm{~h}$ after the cessation of the irrigation) (Alaoui \& Helbling, 2006). Low $\Delta \theta_{\delta}$ values indicated the draining of micropores, whereas high values indicated the 
draining of larger pores, such as macropores or cracks, and pointed out preferential flow (Alaoui, Germann, Jarvis, \& Acutis, 2003).

4) Dye Infiltration Experiment

A dye infiltration experiment was carried out to visualize the heterogeneity of dye-tracer distribution pathways. To this end, $240 \times 10^{-3} \mathrm{~m}^{3}$ of dye-tracer solution were prepared by diluting $880 \mathrm{~g}$ of Brilliant Blue FCF powder also known as food dye E-133 (Flury \& Flühler, 1995) - in tap water (final concentration $=3.7 \mathrm{~g} / 10^{-3} \mathrm{~m}^{3}$ ). The prepared solution was applied at site 1 and site 2 for $3 \mathrm{~h}$ at a constant rate of $24 \mathrm{~mm} \mathrm{~h}^{-1}$ by using a rainfall simulator covering a $1 \mathrm{~m}^{2}$ area. Being neutral or anionic (depending on the $\mathrm{pH}$ ), Brilliant Blue (BB) is not heavily adsorbed by negatively charged soil constituents.

One day after infiltration, a soil pit was excavated and six vertical profiles $(0,0.20,0.40,0.60,0.80$, and $1.00 \mathrm{~m}$ from the edge of the area treated with the rainfall simulator) were prepared. A rubber string grid $(1.0 \times 0.7 \mathrm{~m})$ was attached in front of each profile. The profiles were photographed with a digital camera (HP Photosmart 945; resolution: 5 megapixels). The resultant digital images had a resolution of approx. $2000 \times 2000$ pixels. The final coverage of the stained areas was determined from profile images according to the procedure described by Alaoui and Goetz (2008). Afterwards, the distribution of the dye coverage with depth was calculated for each image by counting the pixels indicating stained soil for each horizontal pixel row of the image.

To allow quantitative estimates of different $\mathrm{BB}$ concentrations, we performed a calibration linking specific colors with corresponding BB concentration ranges. Ten standard solutions were prepared (BB concentration: 0.1, 0.5, $1,2,4,6,20,40,80$ and $\left.150 \mathrm{~g} / 10^{-3} \mathrm{~m}^{3}\right)$. These solutions were photographed with the same camera under the same light conditions as in the field. The surface density of BB was then estimated to a depth of $0.80 \mathrm{~m}$ for both sites (site 1 and site 2).

\section{5) Surface Runoff Estimation}

To estimate surface runoff resulting from shear stress, we considered previous measurements of surface runoff on a $16 \mathrm{~m}^{2}$ surface area with a $15^{\circ}$ slope, carried out on similar soil texture (clay loam) and with a similar tractor (Hürlimann Prestige 88) and treatment design (Alaoui, Spiess, Beyeler, \& Weingartner, 2012). In the previous study, the surface runoff was measured at different irrigation intensities of 24,36 , and $48 \mathrm{~mm} \mathrm{~h}^{-1}$. In this study, we calculated surface runoff at an irrigation intensity of $100 \mathrm{~mm} \mathrm{~h}^{-1}$ according to a linear regression obtained from the measurements of the previous study $\left(24,36\right.$, and $\left.48 \mathrm{~mm} \mathrm{~h}^{-1}\right)$ with $R^{2}$ equal to 0.91 . We hypothesized in this study that under similar conditions such as a field slope of $15^{\circ}$ and shear stress (treatment with $27 \%$ slip), the observed-reduction in water flowing from macropores from site 1 to site 2, calculated at $0.15 \mathrm{~m}$ topsoil depth (see section 3.4), is expected to be transferred to surface runoff. The main aim of these calculations was to evaluate the impact of shear stress at different rainfall intensities in hillslope areas with a $15^{\circ}$ field slope. The theoretical rainfall intensity of $100 \mathrm{~mm} \mathrm{~h}^{-1}$ represented heavy storms corresponding to hourly annual maximum intensities with return periods between 10 and 100 yrs. for the northern part of Switzerland.

\subsection{Models}

\subsubsection{Mechanical Model}

The employed model simulated soil-tire contact stress and traction performance of the tractor. It was based on the following assumptions: the soil behaves like a plastic non-linear medium; the wheel spins in steady-state motion at a low velocity; the tire deforms in linear elasticity; the soil-tire contact surface in the longitudinal direction is parabolic in shape, with the apex at the rear point of contact; and the wheel-soil interaction is two dimensional (plane strain problem).

The stress state (shear stress and normal stress) distribution at the soil-tire contact surface was simulated according to the soil-tire interaction model presented by Shmulevich and Osetinsky (2003) and Osetinsky and Shmulevich (2004). Load transfer from the front axle to the rear axle by pulling, and the lowest threshold slip beyond which topsoil shear would occur based on the soil shear stress-maximal soil strength concept of Mohr-Coulomb (Battiato, Diserens, Laloui, \& Sartori, 2013) were taken into account in the simulation. The model was adapted for a mechanical front-wheel drive vehicle according to Battiato and Diserens (2013) and integrated in the tool TASC V3.0 (second module) (Battiato, 2014). The soil and the tractor specifications included in the simulation are reported in Table 4. 
Table 4. Soil and tractor parameters for the simulation of slip value beyond which soil shear occurs with corresponding traction force, shear stress, and normal stress (TASCV3.0 - module 2)

\begin{tabular}{ll}
\hline Tractor parameters & \\
\hline Traction & 4 driven wheels \\
Wheelbase $(\mathrm{m})$ & 2.34 \\
Tire description (front; rear) & $380 / 85 \mathrm{R} 24 ;$ 420/85R 34 \\
Tire width (front; rear) $(\mathrm{m})$ & $0.39 ; 0.44$ \\
Tire unloaded radius (front; rear) $(\mathrm{m})$ & $0.63 ; 079$ \\
Tire rolling radius (front; rear) $(\mathrm{m})$ & $0.61 ; 0.76$ \\
Tire inflation pressure (front; rear) $(\mathrm{kPa})$ & $160 ; 160$ \\
Tire stiffness (front; rear) $\left(\mathrm{kN} \mathrm{m}^{-1}\right)$ & $330 ; 434$ \\
Stationary wheel load (front; rear) $(\mathrm{kN})$ & $9.1 ; 10.9$ \\
Drawbar height (m) & 0.83 \\
Theoretical speed ratio & 0.99 \\
\hline Soil parameters & \\
\hline Soil texture & clay loam and loam \\
Topsoil hardness (penetration resistance to screwdriver) & semi-firm \\
Modulus of deformation $K\left(\mathrm{kN} \mathrm{m}{ }^{-(\mathrm{n}+2)}\right)$ & 5500 \\
Exponent of deformation $n$ & 0.85 \\
Cohesion $c(\mathrm{kPa})$ & 14.70 \\
Angle of shear resistance $\varphi\left({ }^{\circ}\right)$ & 25 \\
Shear deformation modulus $k(\mathrm{~m})$ & 0.0093 \\
\hline
\end{tabular}

\subsubsection{Hydrological Model}

The MACRO model (Jarvis, 1994) is a dual-porosity model that simulates water and solute transport in macroporous soil. The model divides the total porosity into macropores and micropores. Water flow in micropores is calculated with the Richards' equation (Richards, 1931), whereas macropore flow is simulated as a power-law function of the saturation level in macropores. The two domains are separated by a boundary water content $\left(\theta_{b}\right)$, a boundary saturated hydraulic conductivity $\left(K_{b}\right)$, and a boundary tension $\left(\Psi_{b}\right)$. An effective diffusion-path length $d$ controls mass exchange between the domains (Table 5).

In this study, the MACRO model was used to quantify the water flowing from macropores at both sites (site 1 with $1 \%$ slip and site 2 with $27 \%$ slip) in order to evaluate the macropore damage due to the applied shear and compressive stress. 
Table 5. MACRO model input parameters: soil hydraulic properties at site 1 (1\% slip) and site 2 (27\% slip)

\begin{tabular}{|c|c|c|c|c|c|c|c|c|c|c|}
\hline \multirow[b]{2}{*}{ Depth (m) } & \multicolumn{10}{|c|}{ Parameters } \\
\hline & $\begin{array}{l}\theta_{s}^{\dagger} \\
\left(\mathrm{m}^{3} \mathrm{~m}^{-3}\right)\end{array}$ & $\begin{array}{l}\theta_{b}^{\ddagger} \\
\left(\mathrm{m}^{3} \mathrm{~m}^{-3}\right)\end{array}$ & $\begin{array}{l}\theta_{r}^{+} \\
\left(\mathrm{m}^{3} \mathrm{~m}^{-3}\right)\end{array}$ & $\begin{array}{l}\Psi_{b}^{\ddagger} \\
(\mathrm{cm})\end{array}$ & $\begin{array}{l}K_{\text {sat }}^{\dagger} \\
\left(\mathrm{mm} \mathrm{h}^{-1}\right)\end{array}$ & $\begin{array}{l}K_{b}^{\ddagger} \\
\left(\mathrm{mm} \mathrm{h}^{-1}\right)\end{array}$ & $\begin{array}{l}d^{\ddagger} \\
(\mathrm{mm})\end{array}$ & $n^{* \neq}$ & $n^{\ddagger}$ & $\begin{array}{l}\alpha^{\ddagger} \\
\left(\mathrm{cm}^{-1}\right)\end{array}$ \\
\hline \multicolumn{11}{|l|}{ Site 1} \\
\hline $0-0.15$ & 0.54 & 0.45 & 0 & 1 & 70 & 0.1 & 20 & 4 & 1.108 & 0.027102 \\
\hline $0.16-0.30$ & 0.54 & 0.45 & 0 & 1 & 70 & 0.1 & 20 & 4 & 1.101 & 0.031269 \\
\hline $0.31-0.45$ & 0.50 & 0.43 & 0 & 1 & 50 & 0.1 & 20 & 4 & 1.096 & 0.027632 \\
\hline $0.46-0.60$ & 0.50 & 0.35 & 0 & 1 & 40 & 0.1 & 20 & 4 & 1.079 & 0.035064 \\
\hline \multicolumn{11}{|l|}{ Site 2} \\
\hline $0-0.15$ & 0.45 & 0.20 & 0 & 1 & 40 & 0.1 & 6 & 4 & 1.050 & 0.000025 \\
\hline $0.16-0.30$ & 0.45 & 0.35 & 0 & 1 & 40 & 0.1 & 6 & 2 & 1.050 & 0.000062 \\
\hline $0.31-0.45$ & 0.45 & 0.33 & 0 & 1 & 40 & 0.1 & 5 & 2 & 1.140 & 0.022394 \\
\hline $0.46-0.60$ & 0.45 & 0.35 & 0 & 1 & 30 & 0.1 & 5 & 2 & 1.148 & 0.028195 \\
\hline
\end{tabular}

Note. ${ }^{\dagger}$ Measured parameters; ${ }^{\star}$ Parameters derived from calibration; $\theta_{s}$ : saturated water content; $\theta_{b}$ : boundary water content; $\theta_{r}$ : residual water content; $\Psi_{b}$ : boundary tension; $K_{\text {sat }}$ : saturated water conductivity; $K_{b}$ : boundary hydraulic conductivity; $d$ : effective diffusion-path length; $n^{*}$ : reflects pore-size distribution index and tortuosity in the macropore system; $n$ and $\alpha$ are van Genuchten's parameters (Simunek et al., 2007).

\section{Results and Discussion}

Results of mechanical and hydraulic measurements are presented in paragraphs 3.1 and 3.2, respectively, whereas modeling results are presented and discussed in paragraph 3.3 for soil stresses and in 3.4 for water dynamics.

\subsection{Mechanical Aspects}

Measured values from tables 1 to 3 were collected for the determination of the stress distribution at the interface soil-tire. At $27 \%$ slip (site 2), the soil was sheared significantly and displaced over a distance of $0.35 \mathrm{~m}$ (Figure 2) under the wheels of a $65 \mathrm{~kW}$ tractor (Table 2). The load acting on the front wheel decreased whereas the load acting on the rear wheel increased with increasing drawbar pull and slip due to the load transfer from the front to the rear axle. This shift caused changes in the geometry of the contact surface, which became smaller under the front wheel and larger under the rear wheel.
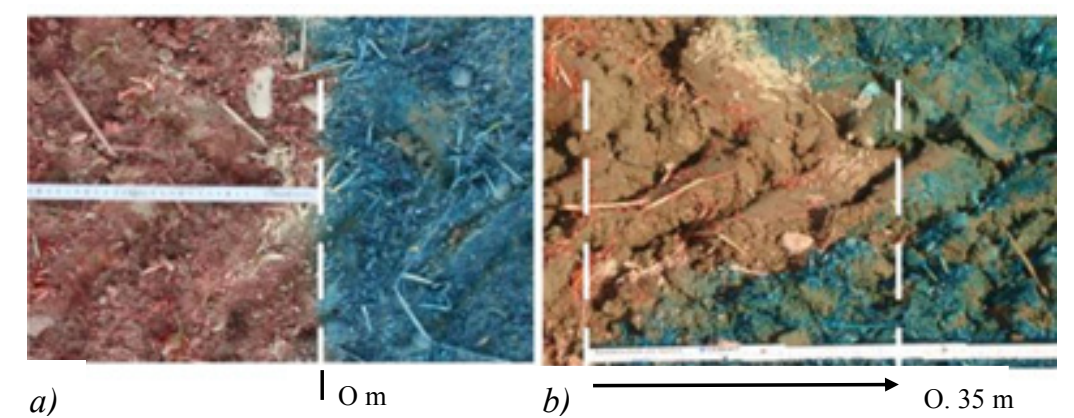

Figure 2. Topsoil deformation owing to tractor traffic, a) longitudinal displacement by $1 \%$ slip (site 1$), b$ ) longitudinal displacement by $27 \%$ slip (site 2)

Normal stress increased with increasing slip from $90.6 \mathrm{kPa}$ (site 1) to $104.4 \mathrm{kPa}$ (site 2) (Figure 3) at topsoil level, exceeding the indicative value of $85 \mathrm{kPa}$ for clay loam soil (Table 1) (Diserens, Chanet, \& Marionneau, 2010). This observation was valid for both axles at $1 \%$ slip (site 1), and for only the rear axle at $27 \%$ slip (site 2). As the slip increased, the maximum shear contact stress rose noticeably for front (from $19.7 \mathrm{kPa}$ to $42.6 \mathrm{kPa}$ ) and 
rear wheels (from $6.0 \mathrm{kPa}$ to $61.6 \mathrm{kPa}$ ) and approached maximal soil strength over a large part of the contact surface (Figure 3).

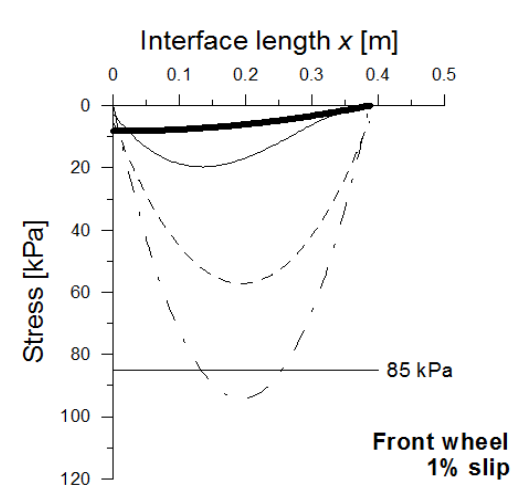

a)

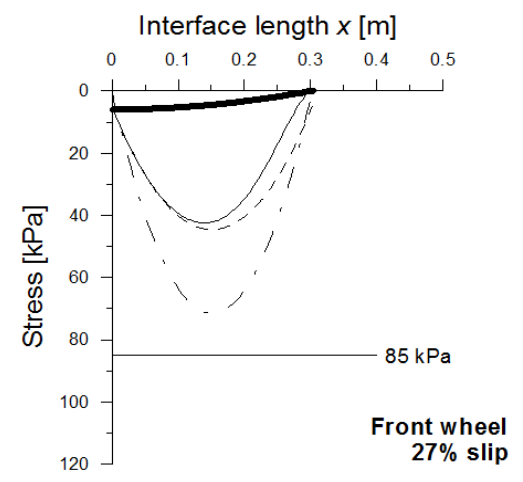

b)

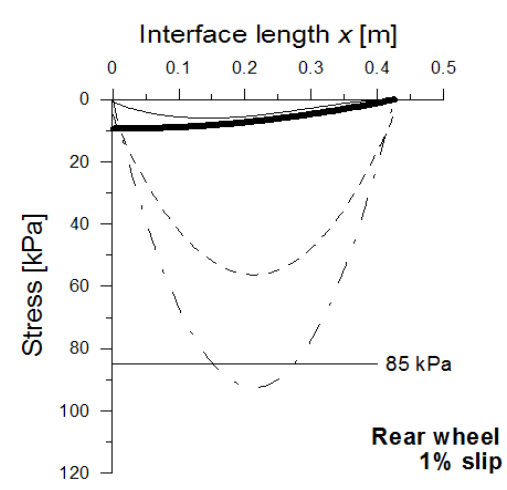

c) soil-tyre $\quad \ldots-$ normal stress $\sigma$

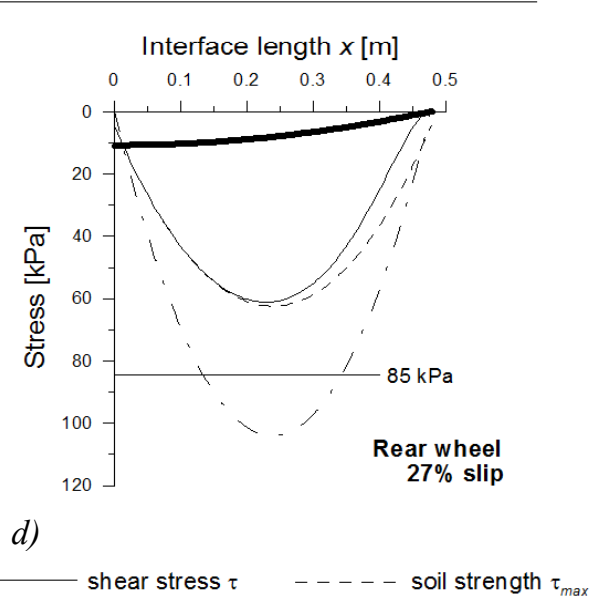

Figure 3. Simulation of the geometry of the soil-tire contact surface, contact stresses included indicative value for normal stress: a) front wheel at $1 \%$ slip; b) front wheel at $27 \%$ slip; $c$ ) rear wheel at $1 \%$ slip; $d$ ) rear wheel at $27 \%$ slip

\subsection{Hydrological Aspects}

According to the statistical analysis, TP at the soil surface $(0-0.15 \mathrm{~m})$ was significantly lower at site $2(\mathrm{TP}=43 \%)$ than at site $1(\mathrm{TP}=54 \%)$ (Figure 4$)$. The TP values measured at both trafficked sites were significantly lower than the value measured at the control site at $0.15 \mathrm{~m}$ depth $(\mathrm{TP}=60 \%)$. This difference tended to persist, albeit to a lesser extent, below $0.15 \mathrm{~m}$. These changes in soil porosity likely resulted from the effects of soil shear acting down to a depth of $0.08 \mathrm{~m}$ and from a normal stress value exceeding $100 \mathrm{kPa}$ at $27 \%$ slip, and reaching already a high value of $93 \mathrm{kPa}$ at $1 \%$ slip (Figure 3). 


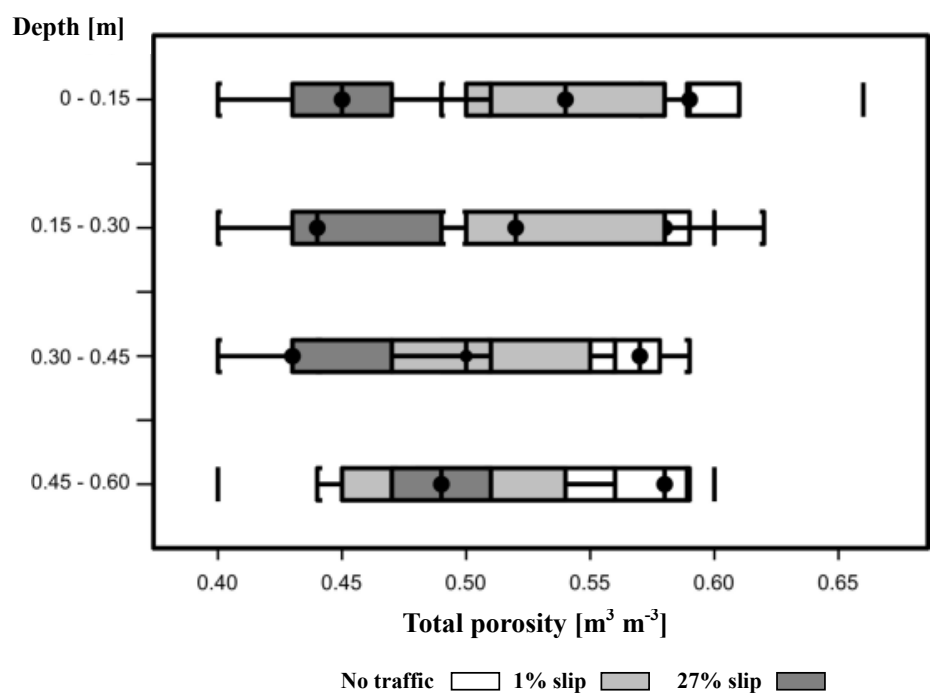

Figure 4. Total porosity measured by no traffic (control site), by $1 \%$ slip (site 1 ), and by $27 \%$ slip (site 2 ), at different depths

At the soil surface ( $0-0.05 \mathrm{~m}$ depth), the macroporosity decreased from $5 \%$ at the control site to $2 \%$ and $0 \%$ by 1 $\%$ slip and by $27 \%$ slip respectively. In all cases, especially at site 2 , the macroporosity values were lower than the indicative value of 7\% (pF 1.8) for agricultural soil (SSSS, 2004) (Figure 5). In comparison, at $0.35 \mathrm{~m}$ depth (subsoil), a causal effect of traffic-related stresses on soil porosity could not be shown. Pore-size distribution was almost identical between the control site and site 1 (Figure 5). However, the decrease of total porosity and the almost complete destruction of macropores at site 2 in the topsoil might be explained by the effect of the high slip level coupled with increasing load at the rear axle exerted by the $65 \mathrm{~kW}$ tractor. The results demonstrated that excessive normal and shear stresses values led to severe reduction of the macroporosity in the topsoil, near the surface.
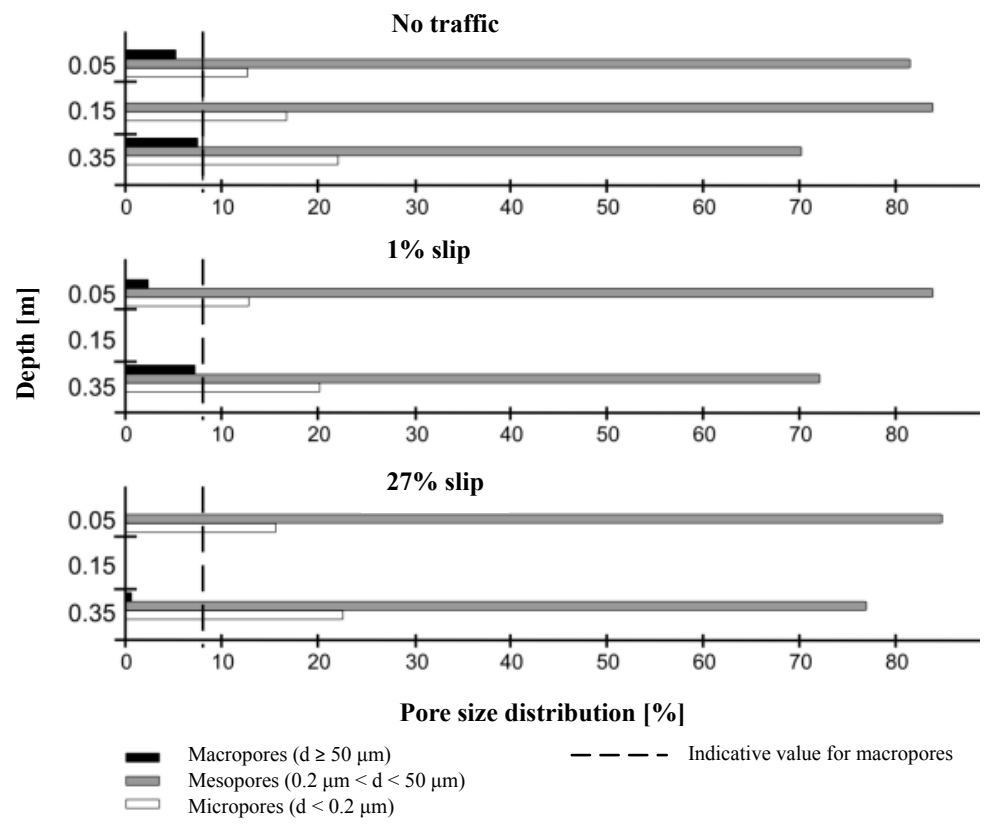

Figure 5. Pore-size distribution by no traffic (control site), by $1 \%$ slip (site 1), and by $27 \%$ slip (site 2 ), and threshold for macropores at different depths 
Otherwise, strong correlations between normal stress and penetration resistance on one part and between penetration resistance and macroporosity on the other part were also be observed by Servadio, Marsili, Vignozzi, Pellegrini, and Pagliai (2005).

A significant decrease in $K_{\text {sat }}$ (mean value) was observed from the control site $\left(8.3 \times 10^{-6} \mathrm{~m} \mathrm{~s}^{-1}\right)$ to site $1(2.8 \times$ $\left.10^{-6} \mathrm{~m} \mathrm{~s}^{-1}\right)$ and to site $2\left(0.14 \times 10^{-6} \mathrm{~m} \mathrm{~s}^{-1}\right)$ at the soil surface between 0 and $0.10 \mathrm{~m}$ depth (Figure 6). At site 2 , $K_{\text {sat }}$ was lower than the indicative value of $1.0 \times 10^{-6} \mathrm{~m} \mathrm{~s}^{-1}$ for agricultural soil (SSSS, 2004). Below $0.10 \mathrm{~m}$ depth, no significant difference in $K_{\text {sat }}$ was observed among all sites. At $1 \%$ slip (site 1), the highest stress state was reached under the front tire $(\sigma=94.2 \mathrm{kPa}$ and $\tau=19.7 \mathrm{kPa})$, which caused a decrease of about $66 \%$ in $K_{\text {sat }}$ (compared with the control). At $27 \%$ slip (site 2), the highest stress state was reached under the rear tire $(\sigma=$ $104.4 \mathrm{kPa}$ and $\tau=61.6 \mathrm{kPa}$ ), causing a reduction of about $98 \%$ in $K_{\text {sat }}$ (compared with the control). The decrease in $K_{\text {sat }}$ from site 1 to 2 was most likely due primarily to the drastic increase in shear stress $(210 \%)$ with high friction force of the lugs on the firm soil, below the loose soil layer, and secondarily to the slight increase in normal contact stress $(11 \%)$.

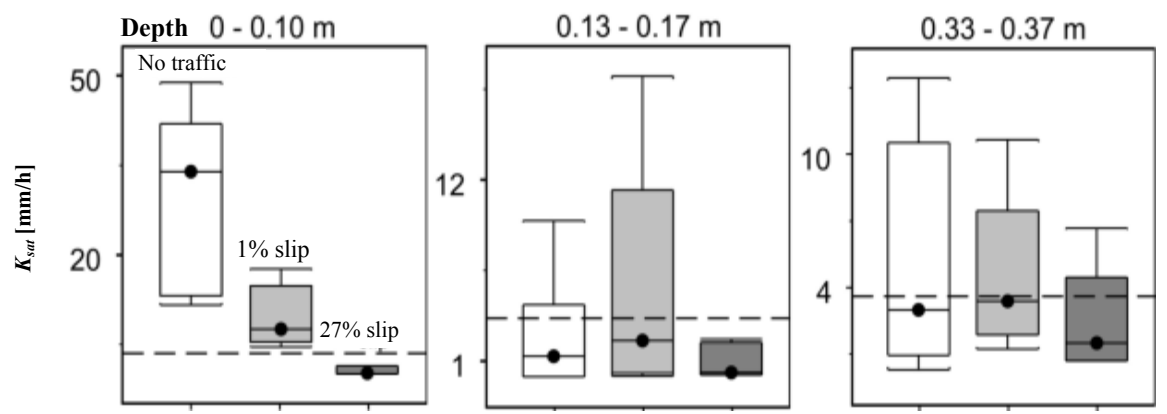

Figure 6. Saturated hydraulic conductivity $K_{\text {sat }}$ (mean values, quartiles and extreme values) measured by no traffic (control site), by $1 \%$ slip (site 1), and by $27 \%$ slip (site 2), at different depths with indicative value; note the different scales on each Y-axis

Between $0.15 \mathrm{~m}$ and $0.35 \mathrm{~m}$, the presence of macropores at site 1 indicated by the $K_{\text {sat }}$ analysis (Figure 6) was confirmed with the dye-tracer analysis (Figure 7). The weak dye-tracer density at $0.30 \mathrm{~m}$ depth at site 1 , trafficked with minimal slip (Figure 7), illustrated that few but intact and efficient macropores were present to transport the major portion of water and solute downward (Alaoui \& Goetz, 2008; Holden \& Gell, 2009), supporting the theory that earthworm burrows act as dominant flow pathways for preferential flow. At the trafficked site with $27 \%$ slip (Figure 7 ), the zone of efficient macropores ( $0.30 \mathrm{~m}$ depth) disappeared, most likely replaced by another type of pores as indicated by the homogeneous distribution of dye-tracer density throughout the soil profile up to $0.50-0.60 \mathrm{~m}$ depth.

The evolution of the water content during the drainage phase (after cessation of the irrigation) revealed a significant difference between sites 1 and 2 (Figure 8). In fact, a drastic decrease in water content was observed at site $1\left(\Delta \theta_{d}=8 \%\right)$, corresponding to a rapid draining of macropores, whereas no significant decrease in water content was observed at site $2\left(\Delta \theta_{d}=0.3 \%\right)$, attesting to the absence of macropores. These observations related to the function of macropores can be expressed quantitatively in terms of water flowing from macropores simulated with the MACRO model (section 3.4). 


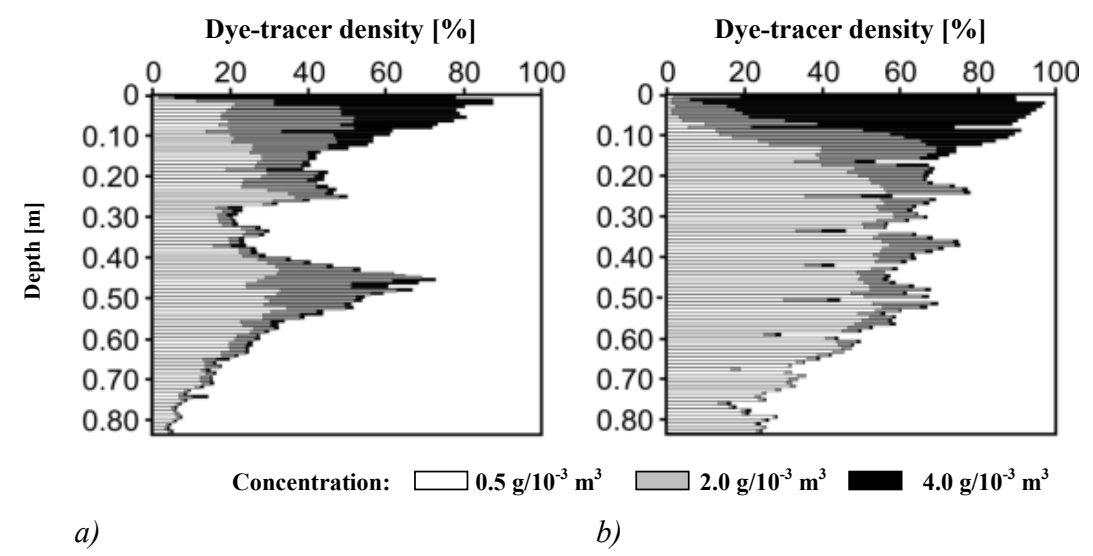

Figure 7. Dye-tracer density versus depth measured $a$ ) by $1 \%$ slip (site 1 ), b) by $27 \%$ slip (site 2 ), the sections presented here were directly under the track of the tractor

These findings show that high mechanical stresses due to slip of a $65 \mathrm{~kW}$ tractor drastically disturbed topsoil structure as illustrated by a decrease in total porosity (Figure 4), a reduction in macroporosity shown by pore-size distribution (Figure 5), and a decrease in $K_{\text {sat }}$ (Figure 6), and consequently could affect water dynamics throughout the entire soil profile (Figures 7 and 8) (section 3.4).
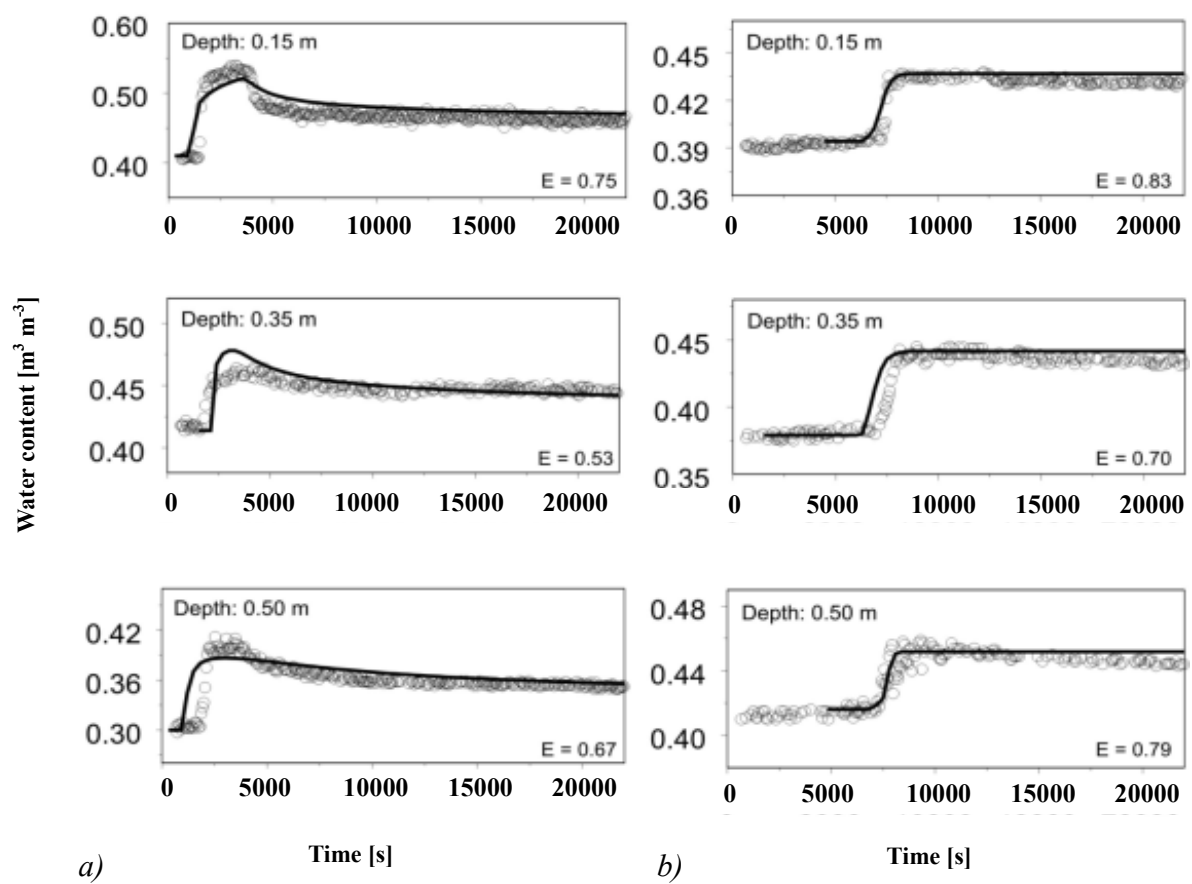

Figure 8. Measured (empty circles) versus simulated (solid lines) water content $a$ ) by $1 \%$ slip (site 1 ), and $b$ ) by $27 \%$ slip (site 2 ) at different depths. $\mathrm{E}=$ model efficiency

\subsection{Modeling Soil Stresses}

The tractor specifications and the measured mechanical soil properties are given in Tables 2 and 3, respectively. Based on measured and simulated values (Table 4) with the tool TASC V3.0 (Battiato, 2014; Diserens \& Battiato, 2013), the normal and shear stress values were calculated separately for the front and rear wheels according to Osetinsky and Shmulevich (2004). The evolution of the stress with slip is given in Figure 9. 


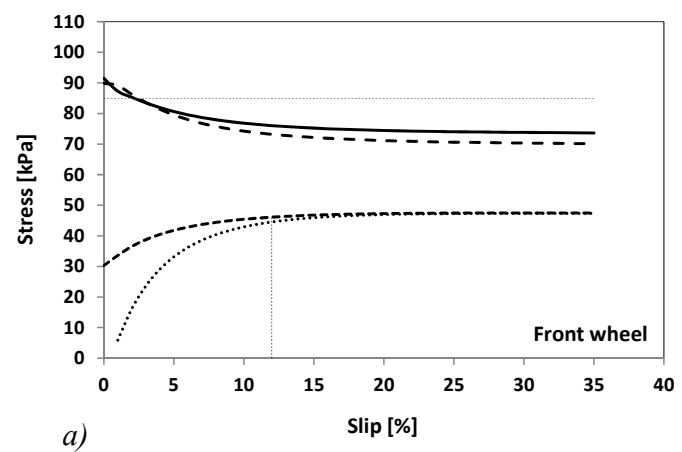

$$
\begin{aligned}
& \text {......... simulated shear stress } \\
& --- \text { simulated normal stress } \\
& \text { soil shear / normal stress limits }
\end{aligned}
$$

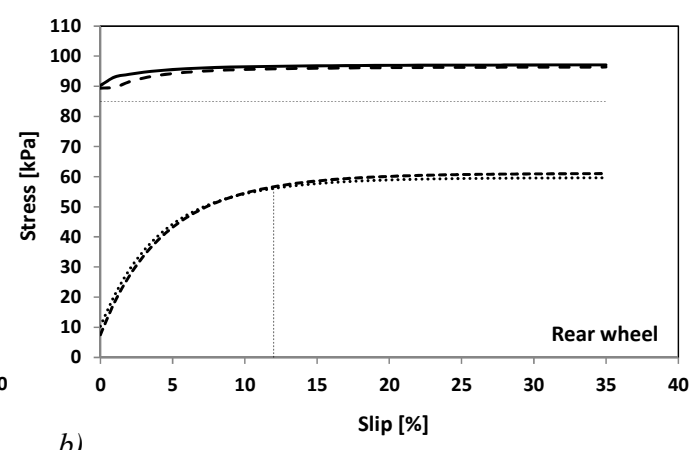

b)

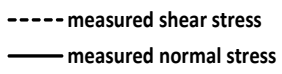

Figure 9. Measured and simulated normal and shear stresses of $a$ ) front and $b$ ) rear wheel

Regarding shear stress, a significant discrepancy between the simulation and the measurements at minimal slip level was observed for the front wheel and could be due to the higher value of rolling radius used in the simulation $(0.61 \mathrm{~m})$ compared with the measured one $(0.59 \mathrm{~m})$ (Tables 2 and 4$)$. For a given shear stress, the simulated slip level on a semi-firm wheat stubble ground was therefore higher than the measured one. Beyond 10 $\%$ slip, the importance of the rolling radius decreased significantly. For both wheels, the simulation as well as the measured values indicated a soil-failure limit at 12\% slip (Figure 9).

The normal stress was determined through soil hardness, width and diameter of the tires, width and length of the contact surface, tire inflation pressure, wheel load, and amount of load transfer. In the simulation, the topsoil was less firm with a modulus of deformation of 5500 (Table 4) compared with the measured value of 8073 (Table 3 ). For the front wheel, with a width of $0.39 \mathrm{~m}$ used in the simulation (Table 4) instead of $0.38 \mathrm{~m}$ obtained from the measurements (Table 2), the length and the width of the contact surface were greater, the traction force and load transfer were higher, and the normal stress acting at soil-tire interface of the front wheel was consequently lower in the simulation than in the calculation based on measurements. Only at low slip $(<5 \%)$, the load transfer caused by a larger rolling radius $(0.61 \mathrm{~m})$ was lower than that caused by a smaller rolling radius $(0.59 \mathrm{~m})$, and therefore simulated wheel load and normal stress were slightly higher than the respective estimates obtained from measurements (Figure 9). For the rear wheel, no significant divergence was observed between measured and simulated values (Figure 9).

\subsection{Modeling Water Dynamics}

Model calibration with water content $(\theta)$ measured at depths of $0.15,0.35$, and $0.50 \mathrm{~m}$ yielded satisfactory results. The model reproduced the measured values closely as shown by the model efficiency (E) that was calculated according to Nash and Sutcliffe (1970) and ranged between 0.53 and 0.83 (Figure 8). Once calibrated for $\theta$ at different depths (Figure 8 and Table 5), the MACRO model was run to calculate the volume of water flowing from macropores by $1 \%$ slip and by $27 \%$ slip (Figure 10). A significant difference was observed between sites 1 and 2 at all depths. In the soil surface $(0.15 \mathrm{~m})$, the water flowing from macropores was $7.0 \times$ $10^{-3} \mathrm{~m}^{3}$ at site 1 and $5.0 \times 10^{-3} \mathrm{~m}^{3}$ at site 2 , corresponding to a difference of about $30 \%$. At $0.35 \mathrm{~m}$ depth, the difference was $52 \%\left(5.0 \times 10^{-3} \mathrm{~m}^{3}\right.$ at site 1 and $2.4 \times 10^{-3} \mathrm{~m}^{3}$ at site 2$)$, and at $0.50 \mathrm{~m}$ depth, the difference was $76 \%\left(3.0 \times 10^{-3} \mathrm{~m}^{3}\right.$ at site 1 and $0.7 \times 10^{-3} \mathrm{~m}^{3}$ at site 2$)$. The difference between the water flowing from macropores at sites 1 and 2 was relatively consistent over time at 0.15 and $0.35 \mathrm{~m}$ depth (Figure 10), likely because of the similar soil texture at the two sites (Table 1). The steadily increasing difference in water flowing between sites 1 and 2 at $0.50 \mathrm{~m}$ depth might have resulted from the small difference in soil texture (Table 1). 

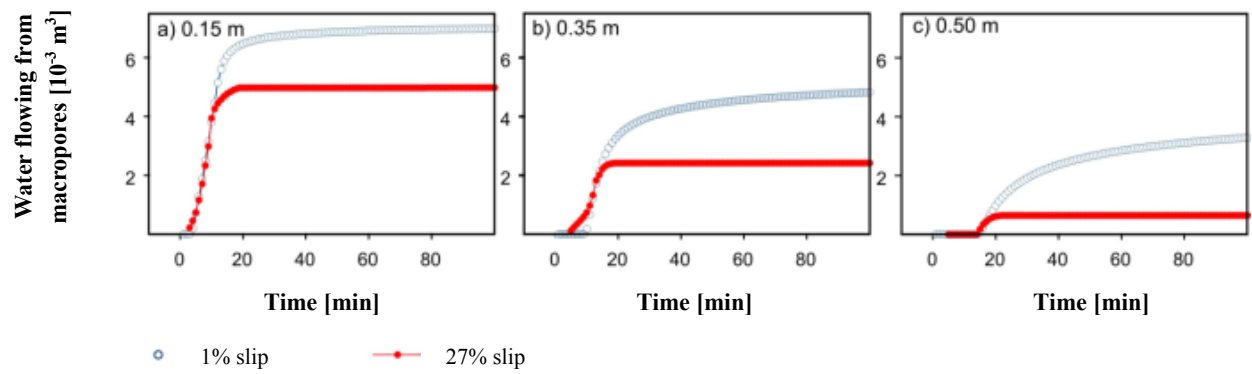

Figure 10. Simulated water flowing from macropores by $1 \%$ slip (site 1 ), and by $27 \%$ slip (site 2 ), estimated at a) $0.15, b) 0.35$, and c) $0.50 \mathrm{~m}$ depth

As mentioned above, we assumed that on a sloping ground $\left(15^{\circ}\right)$, the reduction in the water flowing from macropores at site 2 is expected to be transferred to surface runoff. Results clearly showed that surface runoff increased with increasing rainfall intensity from 24 to $100 \mathrm{~mm} \mathrm{~h}^{-1}$ and increased more on soil trafficked by $27 \%$ slip than on soil trafficked by $1 \%$ slip (Table 6). In fact, at a rainfall intensity of $100 \mathrm{~mm} \mathrm{~h}^{-1}$ on sheared soil (site 2 ), the runoff coefficient was 1.00 indicating a predisposition zone with the highest risk (100\%) of surface runoff excess (Markart et al., 2004; Alaoui, Spiess, Beyeler, \& Weingartner, 2012). This estimate implies that the entire amount of rainfall $(100 \%)$ would be routed to surface runoff $\left(=100000 \mathrm{~m}^{3}\right.$ in the case of a grassland with a surface area of $1 \mathrm{~km}^{2}$ and rainfall intensity of $100 \mathrm{~mm} \mathrm{~h}^{-1}$ ) (Table 6). We expect that in soil conservation systems without plowing, the herein identified changes could have significant impacts on soil erosion and flooding for steeper grounds $\left(>15^{\circ}\right)$ and larger surface areas than those considered in our study.

Table 6. Runoff coefficient (RC) and surface runoff (SR) as affected by soil deformation under different rainfall intensities

\begin{tabular}{|c|c|c|c|c|c|c|c|c|}
\hline \multirow{3}{*}{ Treatment } & \multicolumn{8}{|c|}{ Intensity $\left(\mathrm{mm} \mathrm{h}^{-1}\right)$} \\
\hline & \multicolumn{2}{|c|}{24} & \multicolumn{2}{|c|}{36} & \multicolumn{2}{|c|}{48} & \multicolumn{2}{|c|}{100} \\
\hline & $\mathrm{RC}(-)$ & $\mathrm{SR}\left(\mathrm{m}^{3}\right)$ & $\mathrm{RC}(-)$ & $\mathrm{SR}\left(\mathrm{m}^{3}\right)$ & $\mathrm{RC}(-)$ & $\mathrm{SR}\left(\mathrm{m}^{3}\right)$ & $\mathrm{RC}(-)$ & $\mathrm{SR}\left(\mathrm{m}^{3}\right)$ \\
\hline $1 \%$ slip & 0.07 & 1680 & 0.24 & 8640 & 0.29 & 13920 & 0.79 & 79000 \\
\hline $27 \%$ slip & 0.09 & 2184 & 0.31 & 11232 & 0.38 & 18096 & 1.00 & $10^{5}$ \\
\hline
\end{tabular}

Note. RC and SR for 24, 36, and $48 \mathrm{~mm} \mathrm{~h}^{-1}$ were measured in situ for minimal slip (Alaoui et al., 2012) and extrapolated $(\S 2.2 .2)$ by $27 \%$ slip, whereas $\mathrm{RC}$ and SR for $100 \mathrm{~mm} \mathrm{~h}^{-1}$ were obtained by linear regression $\left(\mathrm{R}^{2}\right.$ : $0.91)$ for a grassland-specific surface area of $1 \mathrm{~km}^{2}$.

Figure 11 shows how an increase of $6.6 \mathrm{kPa}$ in normal stress under the rear wheel resulted in a loss of macropore water flowing of $2.1 \times 10^{-3} \mathrm{~m}^{3}$. For comparison, to produce the same loss in water flowing from macropores, an increase of $38.7 \mathrm{kPa}$ in shear stress would be required. It is noteworthy that both stresses (shear and normal) were combined in the deformation process in which normal stress dominated. These results agree with those from laboratory experiments carried out with a simple shear apparatus (Battiato, 2014). The soil-failure limit indicated in figure 11 corresponded to $12 \%$ slip and was in line with that identified by Battiato (2014). It implied that major loss of water flowing from macropores occurred between $1 \%$ and $12 \%$ slip over the modeled range of stresses. 


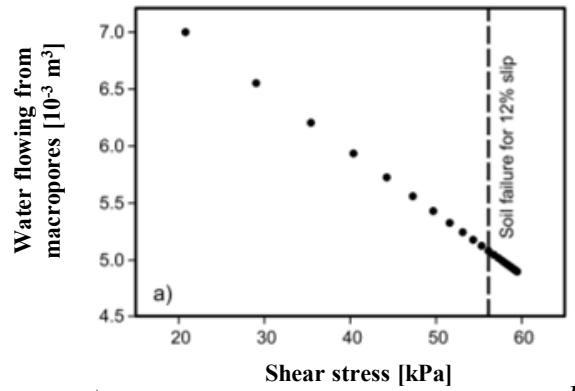

a)

b)

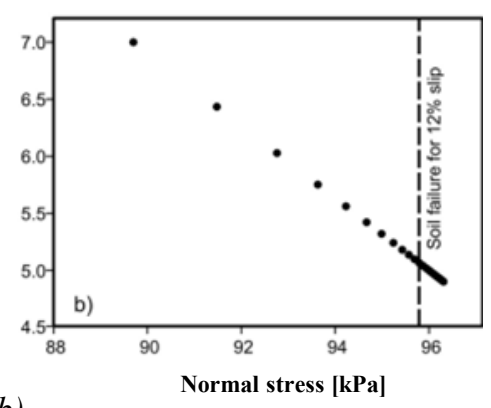

Figure 11. Simulated water flowing from macropores $a$ ) vs. simulated shear stress and $b$ ) vs. simulated normal stress

Because plastic volumetric strain is always linked to proportional alteration in a three-phase system (air, water, soil matrix), hydraulic soil properties have become an essential feature in geotechnical engineering with major interest in soil liquefaction processes. A number of hydro-mechanical elastoplastic constitutive models for saturated soils have been proposed. However, not only saturated soils but also unsaturated soils are affected by liquefaction (Khalili, Habte, \& Zargarbashi, 2008; Bian \& Shahrour, 2009; Arairo, Prunier, Djeran-Maigre, \& Millard, 2014). Furthermore, most of the investigations have been carried out under laboratory conditions and have yet to be conducted in the field. In addition, each soil deformation has to be coupled to hydraulic properties, because deformation and failure in soils depend on the advection and diffusion processes and their history and vice versa (Horn, Richards, Baumgartl, \& Wiermann, 1998).

Despite the tremendous effort in this area of research, no attempts have been made to link the changes in the mechanical and hydraulic properties caused by soil deformation with surface runoff generation in hillslope soils, likely because it is difficult to bridge the gap between lab (measurements of mechanical stresses) and field investigations (measurements of surface runoff).

Although we assume a linear relationship between shear stress and water flowing from macropores (between two single values, namely $1 \%$ and $27 \%$ slip), it will be necessary to conduct detailed measurements at different slip levels and to determine the corresponding surface runoff under various natural conditions. This will help to set a threshold value of the stress beyond which surface runoff will occur for various soil and external conditions in order to better protect soil from erosion and floods on the landscape scale.

\section{Conclusions}

A combination of mechanical and hydraulic approaches and of measurements and modeling enabled us to observe close causal effects between mechanical stress at the tire-soil interface and surface runoff generation. Our results showed that excessive normal and shear stress severely affect the soil structure by drastically reducing macroporosity and saturated hydraulic conductivity in the topsoil. Modeling results also showed that the amount of water flowing from topsoil macropores decreases markedly in soil affected by a high level of wheel slip. Considering a $15^{\circ}$ slope, and assuming that a loss in vertical water flow would be transformed into surface runoff under the combined effects of field slope and increased rainfall intensity, we calculated that the runoff coefficient for a rainfall intensity of $100 \mathrm{~mm} \mathrm{~h}^{-1}$ and duration of $1 \mathrm{~h}$ would increase to 0.79 at site 1 with minimum wheel slip (1\%) and to 1.00 at site 2 with high wheel slip $(27 \%)$. Further field tests are needed to establish consistent computerized links between mechanical stress and surface runoff at different slip levels. We expect that this will make it possible to identify the threshold stress value beyond which surface runoff and erosion are generated: a key piece of information when it comes to supporting farmers in the use of machinery.

\section{Acknowledgements}

All the authors wish to acknowledge the Swiss Federal Office for the Environment FOEN and the tire manufacturer Michelin for their respective financial contributions.

\section{References}

Alakukku, L. (1996). Persistence of soil compaction due to high axle load traffic: I. Short-term effects on the properties of clay and organic soils. Soil Till. Res., 37, 211-222.

Alaoui, A., Spiess, P., Beyeler, M., \& Weingartner, R. (2012). Up-scaling surface runoff from plot to catchment 
scale. Hydrol. Res., 43(4), 531-546. http://dx.doi.org/doi:10.2166/nh.2012.057

Alaoui, A., \& Goetz, B. (2008). Dye tracer and infiltration experiments to investigate macropore flow. Geoderma, 144, 279-286. http://dx.doi.org/10.1016/j.geoderma.2007.11.020

Alaoui, A., \& Helbling, A. (2006). Evaluation of soil compaction using hydrodynamic water content variation: comparison between compacted and non-compacted soil. Geoderma, 134, 97-108. http://dx.doi.org/10.1016/j.geoderma.2005.08.016

Alaoui, A., Germann, P., Jarvis N., \& Acutis, M. (2003). Dual-porosity and kinematic wave approaches to assess the degree of preferential flow in an unsaturated soil. Hydrol. Sci. J., 48(3), 455-472.

Ansorge, D., \& Godwin, R. (2006). High Axle Load - Track - Tire Comparison. In R. Horn, H. Fleige, S. Peth \& X. Peng (Eds.), Soil Management for Sustainability (pp. 9-14). Advances in Geoecology 38. Reiskirchen, Germany, Catena Verlag, GeoEcology.

Arairo, W., Prunier, F., Djeran-Maigre, I., \& Millard, A. (2014). On the use of effective stress in three-dimensional hydro-mechanical coupled model. Comput. Geotech., 58, 56-68. http://dx.doi.org/10.1016/j.compgeo.2014.01.014

Arvidsson, J., Trautner, A., \& Keller, T. (2002). Influence of Tyre Inflation Pressure on Stress and Displacement in the Subsoil. In M. Pagliai \& R. Jones (Eds.), Sustainable Land Management-Environmental Protection. A Soil Physical Approach (pp. 331-338). Advances in Geoecology 35. Reiskirchen, Germany, Catena Verlag, GeoEcology.

Ball, B. C. (1981). Pore characteristics of soils from two cultivation experiments as shown by gas diffusivities and permeabilities and air-filled porosities. J. Soil Sci., 32, 465-481.

Bastgen, H. M., \& Diserens, E. (2009). q-value for calculation of pressure propagation in arable soils taking topsoil stability into account. Soil Till. Res., 102, 138-143. http://dx.doi.org/10.1016/j.still.2008.08.005

Battiato, A. (2014). Soil-Tyre Interaction Analysis for Agricultural Tractors: Modelling of Traction Performance and Soil Damage (PhD Thesis, p. 165). Università degli Studi di Padova. Dipartimento di Territorio e Sistemi Agro Forestali (T.E.S.A.F.). Scuola di Dottorato di Ricerca in Territorio Ambiente Risorse e Salute (T.A.R.S.) Indirizzo: Tecnologie Meccaniche dei Processi Agricoli e Forestali, Padova, Italy. Ciclo XXVI.

Battiato, A., \& Diserens, E. (2013). Influence of tyre inflation pressure and wheel load on the traction performance of a $65 \mathrm{~kW}$ MFWD tractor on a cohesive soil. Journal of Agricultural Science, 5(8), 197-215. http://dx.doi.org/10.5539/jas.v5n8p197

Battiato, A., Diserens, E., Laloui, L., \& Sartori, L. (2013). A mechanistic approach to topsoil damage due to slip of tractor tyres. J. Agric. Sci. Appl., 2(3), 160-168.

Bekker, M. G. (1960). Off-the-Road Locomotion. Ann Arbor, Michigan, University of Michigan Press.

Bian, H., \& Shahrour, I. (2009). Numerical model for unsaturated sandy soils under cyclic loading: application to liquefaction. Soil Dyn. Earthq. Eng., 29, 237-244.

Blanco-Canqui, H., Claassen, M. M., \& Stone, L. R. (2010). Controlled traffic impacts on physical and hydraulic properties in an intensively cropped no-till soil. Soil Sci. Soc. Am. J., 74, 2142-2150. http://dx.doi.org/doi:10.2136/ssaj2010.0061

Boone, F. R. (1988). Weather and other environmental factors influencing crop responses to tillage and traffic. Soil Till. Res., 11, 283-324. http://dx.doi.org/10.1016/0167-1987(88)90004-9

Christensen, J. H., \& Christensen, O. B. (2003). Severe summertime flooding in Europe. Nature, 421, 805-806.

da Silva, A. P., Kay, B. D., \& Perfect, E. (1994). Characterization of the least limiting water range of soils. Soil Sci. Soc. Am. J., 58, 1775-1781. http://dx.doi.org/10.2136/sssaj1994.03615995005800060028x

Dirksen, C. (1999). Soil Physics Measurements. Reiskirchen, Germany, Catena Verlag GeoEcology.

Diserens, E., \& Battiato, A. (2013). TASC V3.0 - Prognose Bodengefährdung und Treibstoffverbrauch. ART-Berichte Nr. 766 (p. 8).

Diserens, E., Chanet, M., \& Marionneau, A. (2010). Machine Weight and Soil Compaction: TASC V2.0.xls - a Practical Tool for Decision-Making in Farming (p. 10). AgEng 2010, Clermont-Ferrand, France, Sept. 7-9, 2010, REF 239.

Diserens, E., \& Spiess, E. (2004). Wechselwirkung zwischen Fahrwerk und Ackerboden. TASC: Eine 
PC-Anwendung zum Beurteilen und Optimieren der Bodenbeanspruchung. FAT Berichte Nr. 613 (p. 16).

Diserens, E., \& Steinmann, G. (2003). In-situ determination of the fracture point of an agricultural soil using the plate penetration test, comparison with the oedometer method and validation (pp. 93-106). Proceedings of the International Conference on Geo-Environmental Engineering, Singapore.

Flury, M., \& Flühler, H. (1995). Tracer characteristics of Brilliant Blue FCF. Soil Sci. Soc. Am. J., 59, $22-27$. http://dx.doi.org/10.2136/22aj1995.03615995005900010003x

Graham, L. P., Hagemann, S., Jaun, S. O., \& Beniston, M. (2007). On interpreting hydrological change from regional climate models. Climatic Change, 81, 97-122. http://dx.doi.org/doi:10.1007/s10584-006-9217-0

Holden, J., \& Gell, K. F. (2009). Morphological characterization of solute flow in a brown earth grassland soil with crane fly larvae burrows (leatherjackets). Geoderma, 152, 181-186. http://dx.doi.org/10.1016/j.geoderma.2009.06.006

Horn, R. (2003). Stress-strain effects in structured unsaturated soils on coupled mechanical and hydraulic processes. Geoderma, 116(1-2), 77-88. http://dx.doi.org/10.1016/S0016-7061(03)00095-8

Horn, R. (2002). Soil Mechanical Properties and Processes in Structured Unsaturated Soils under Various Landuse and Management Systems. In M. Pagliai, \& R. Jones (Eds.), Sustainable Land Management Environmental Protection (pp. 305-318). Advances in Geoecology: 35, Catena Verlag GmbH, Reiskirchen, Germany.

Horn, R. (1981). Eine Methode zur Ermittlung der Druckbelastung von Böden anhand von Drucksetzungsversuchen. Zeitschrift für Kulturtechnik und Flurbereinigung, 22(1), 20-26.

Horn, R., \& Rostek, J. (2000). Subsoil Compaction Processes - State of Knowledge. In R. Horn, J. J. H. van den Akker \& J. Arvidsson (Eds.), Subsoil Compaction - Distribution, Processes and Consequences (pp. 44-55). Advances in Geoecology 32. Reiskirchen, Germany, Catena Verlag GeoEcology.

Horn, R., Richards, B. G., Gräsle, W., Baumgartl, T., \& Wiermann, C. (1998). Theoretical principles for modelling soil strength and wheeling effects - A review. Journal of Plant Nutrition and Soil Science, 161(4), 333-346. http://dx.doi.org/10.1002/jpln.1998.3581610402

Jarvis, N. J. (1994). The MACRO Model Version 3.1 - Technical description and sample simulations (Reports and dissertations No. 19, p. 51). Department of Soil Science, Swedish University of Agricultural Sciences, Uppsala, Sweden.

Khalili, N., Habte, M. A., \& Zargarbashi, S. (2008). A fully coupled flow deformation model for cyclic analysis of unsaturated soils including hydraulic and mechanical hystereses. Comput. Geotech., 35, 872-889. http://dx.doi.org/10.1016/j.compgeo.2008.08.003

Kirby, J. M. (1991). Strength and deformation of agricultural soil: measurement and practical significance. Soil Use Management, 7, 223-229. http://dx.doi.org/10.1111/j.1475-2743.1991.tb00878.x.

Klute, A., \& Dirksen, C. (1986). Hydraulic Conductivity of Saturated Soil - Constant Head Method. In A. Klute (Ed.), Methods of Soil Analysis (pp. 694-700). Part 1. Physical and Mineralogical Methods - Agronomy Monograph No. 9 (2nd ed.). Madison, Wisconsin, American Society of Agronomy - Soil Science Society of America.

Kulli, B., Gysi, M., \& Flühler, H. (2003). Visualizing soil compaction based on flow pattern analysis. Soil Till. Res., 70, 29-40.

Lines, J. A., \& Murphy, K. (1991). The stiffness of agricultural tractor tyres. J. Terramechanics, 28(1), 49-64. http://dx.doi.org/10.1016/0022-4898(91)90006-R

Markart, G., Kohl, B., Sotier, B., Schauer, T., Bunza, G., \& Stern, R. (2004). Provisorische Geländeanleitung zur Abschätzung des Oberflächenabflussbeiwertes auf alpinen Boden-/Vegetationseinheiten bei konvektiven Starkregen [A simple Code of Practice for Assessment of Surface Runoff Coefficients for Alpine Soil/Vegetation Units in Torrential Rain] (Version 1.0). BFW Dokumentationen. Bundesamt und Forschungszentrum für Wald, Wien, Austria.

Nash, J. E., \& Sutcliffe, J. V. (1970). River flow forecasting through conceptual models, part I - A discussion of principles. J. Hydrol., 10, 282-290. http://dx.doi.org/10.1016/0022-1694(70)90255-6

O’Sullivan, M. F., Robertson, E. A. G., \& Henshall, J. K. (1999). Shear effects on gas transport in soil. Soil Till. Res., 50, 73-83. 
Osetinsky, A., \& Shmulevich, I. (2004). Traction performance simulation of a pushed/pulled driven wheel. Trans. ASAE, 47(4), 981-994.

Pagliai, M. (1998). Soil porosity aspects. Int. Agrophys., 4, 215-232.

Peschke, G., Etzenberg, C., Müller, G., Töpfer, J., \& Zimmermann, S. (1999). Die Abflussbildung in ihrer Abhängigkeit von der wirksamen Kombination flächenvariabler Einflussfaktoren und Gebietszustand [Runoff generation depending from the effective combination of spatial variable factors and antecedent conditions]. Abschlussbericht zur Forschung, DFG-Schwerpunkt Programm "Regionalisierung in der Hydrologie.” Internationales Hochschulinstitut Zittau, Zittau, Germany.

Pichlmaier, B. R. (2012). Traktormanagement für Traktoren (PhD Thesis, p. 209). Dissertation der Technischen Universität München, Institut für Maschinen- und Fahrzeugtechnik. Lehrstuhl für Fahrzeugtechnik, München, Germany.

Reszkowska, A., Krümmelbein, J., Gan, L., Peth, S., \& Horn, R. (2011). Influence of grazing on soil water and gas fluxes of two Inner Mongolian steppe ecosystems. Soil Till. Res., 111, 180-189. http://dx.doi.org/10.1016/j.still.2010.10.003

Richards, L. A. (1931). Capillary conduction of liquids in porous mediums. Physics, 1, 318-333.

Roth, K., Schulin, R., Flühler, H., \& Attinger, W. (1990). Calibration of time domain reflectometry for water content measurement using a composite dielectric approach. Water Resour. Res., 26, 2267-2274. http://dx.doi.org/10.1029/WR026i010p02267

Scheffer, F., \& Schachtschabel, P. (1998). Lehrbuch der Bodenkunde. Ferdinand Enke Verlag Stuttgart. 14 Aufl., $494 \mathrm{~S}$.

Scherrer, S., \& Naef, F. (2003). A decision scheme to identify dominant flow processes at the plot-scale for the evaluation of contributing areas at the catchments-scale. Hydrol. Proc., 17, 391-401.

Schwieger, H. (1996). Untersuchung neuartiger Laufwerke und lasergestütze Erfassung der Reifen-/ Bodenverformung (PhD Thesis, p. 166). Forschungsbericht Agrartechnik des Arbeitskreises Forschung und Lehre der Max-Eyth-Gesellschaft Agrartechnik im VDI (VDI-MEG), Kiel, Germany.

Servadio, P., Marsili, A., Vignozzi, N., Pellegrini, S., \& Pagliai, M. (2005). Effects on some soil qualities in central Italy following the passage of four wheel drive tractor fitted with single and dual tires. Soil Till. Res., 84, 87-100. http://dx.doi.org/10.1016/j.still.2004.09.018

Simunek, J., Sejna, M., \& van Genuchten, M. T. (2007). The HYDRUS Software Package for Simulating the Two- and Three-Dimensional Movement of Water, Heat, and Multiple Solutes in Variably-Saturated Media. PC-Progress, Prague, Czech Republic.

Shmulevich, I., \& Osetinsky, A. (2003). Traction performance of a pushed/pulled drive wheel. J. Terramech., 40, 35-50. http://dx.doi.org/10.1016/j.jterra.2003.09.001

SSSS. (2004). Definition und Erfassung von Bodenschadverdichtungen. Positionspapier der BGS-Plattform Bodenschutz. Swiss Society of Soil Science (SSSS) (Document 13, p. 56).

Steiner, M. (1979). Analyse, Synthese und Berechnungsmethoden der Triebkaft-Schlupf-Kurve von Luftreifen auf nachgiebigem Boden (PhD Thesis, p. 190). Forschungsbericht Agrartechnik des Arbeitskreises Forschung und Lehre der Max-Eyth-Gesellschaft (MEG) 33. München, Germany.

Stettler, M., Keller, T., Schjønning, P., Lamandé, M., Lassen, P., Pedersen, J., \& Weisskopf, P. (2010). Terranimo $^{\circledR}$ - a web-based tool for assessment of the risk of soil compaction due to agricultural field traffic (p. 7). AgEng 2010, Clermont-Ferrand, France, Sept. 7-9, 2010, REF 384.

van den Akker, J. J. H. (2004). SOCOMO: a soil compaction model to calculate soil stresses and the subsoil carrying capacity. Soil Till. Res., 79, 113-127. http://dx.doi.org/10.1016/j.still.2004.03.021

van den Akker, J. J. H. (1997). Construction of a wheel-load bearing capacity map of the Netherlands. Proceedings of the $14^{\text {th }}$ ISTRO Conference July 27 - Aug. 1, 1997, Pulawy, Poland. Polish Society of Agrotechnical Sciences. Bibliotheca Fragmenta Agronomica 2A/97, 15-18.

Vogeler, I., Horn, R., Wetzel, H., \& Kruemmelbein, J. (2006). Tillage effects on soil strength and solute transport. Soil Till. Res., 88, 193-204. http://dx.doi.org/10.1016/j.still.2005.05.009

Wiermann, C. (1998). Auswirkungen differenzierter Bodenbearbeitung auf die Bodenstabilität und das Regenerationsvermögen lössbürtiger Ackerstandorte. Schriftenreihe Institut für Pflanzenernährung und 
Bodenkunde. CAU Kiel, Germany.

Wong, J. Y. (1980). Data processing methodology in the characterization of the mechanical properties of terrain. J. Terramechanics, 17(1), 13-41. http://dx.doi.org/10.1016/0022-4898(80)90014-2

\section{Copyrights}

Copyright for this article is retained by the author(s), with first publication rights granted to the journal.

This is an open-access article distributed under the terms and conditions of the Creative Commons Attribution license (http://creativecommons.org/licenses/by/3.0/). 